\title{
Pioneers, leaders and followers in multilevel and polycentric climate governance
}

\section{Rüdiger K.W. Wurzel ${ }^{a}$, Duncan Liefferink ${ }^{b}$ and Diarmuid Torney ${ }^{c}$}

${ }^{a}$ School of Law and Politics, University of Hull, UK; ${ }^{b}$ Institute for Management Research, Department of Political Sciences of the Environment, Radboud University Nijmegen, the Netherlands; 'School of Law and Government, Dublin City University, Ireland.

\begin{abstract}
This contribution assesses the roles and functions of leaders, pioneers and followers in multilevel and polycentric climate governance. While leaders usually actively seek to attract followers, this is not normally the case for pioneers. We address the following core research questions: (1) Who can be a leader/pioneer?; (2) Why do actors become leaders/pioneers?; (3) How do leaders/pioneers act?; and, (4) How do leaders/pioneers attract followers? In doing so we differentiate between structural, entrepreneurial, cognitive and exemplary leadership and assess the dynamics between leaders/pioneers and followers in climate governance. State-centred, multilevel governance and polycentric governance concepts place different emphasis on the roles played by different types of leadership/pionieership in climate governance. We argue that climate leaders and pioneers can use different types of leadership and often must act (either simultaneously or sequentially) at different levels of climate governance to achieve their ambitions.
\end{abstract}

KEYWORDS Climate change, leaders, pioneers, followers, laggards, multilevel governance, polycentric governance

\section{Introduction}

The environmental governance literature has seen a proliferation of analytical terms to describe actors who try to engender change for the improvement of the environment/climate, such as entrepreneur, forerunner, front runner, first mover, leader, lead state, pace setter, pioneer and trend setter (Liefferink and Wurzel 2017, for the general 
leadership literature see Rhodes and t'Hart 2014, p.3). This proliferation of concepts has inhibited the development of cumulative, theory-guided research on environmental and climate governance. Leaders and pioneers, which are the most commonly used terms in this burgeoning literature, are widely seen as agents of change who are of central importance for climate change mitigation and adaptation (Liefferink and Wurzel 2018, p. 135). However, the precise ways in which different types of leaders and pioneers act and interact with followers in multilevel and polycentric climate governance structures have attracted much less scholarly attention (but see e.g. Torney 2015).

This introduction and the other contributions to this Volume take as an analytical starting point the differentiation that leaders usually actively seek to attract followers while this is not normally the case for pioneers (Liefferink and Wurzel 2017). Although not primarily interested in attracting followers, pioneers may nevertheless be emulated by others. The actual impact of leaders and pioneers, which needs to be established empirically, is dependent on both their own actions and the ensuing dynamics or stalemates with followers and laggards.

Early leadership studies focused on the actions, strategies and motives of powerful individuals such as American Presidents (e.g. Burns 1978). The IR environmental leadership literature shifted the focus to lead states and their actions in international negotiations (e.g. Young 1991, Underdal 1994). Some scholarly attention was paid early on also to international organisations (IOs) and the supranational European Union (EU) (e.g. Rehbinder and Stewart 1985) and subnational actors (e.g. Freeman 1996). The more specialised climate governance literature quickly took on a multi-actor perspective which focused not only on states but also on the EU (e.g. Grubb and Gupta 2000, Wurzel et al. 2017a), businesses (e.g. Grant 2011), NGOs (e.g. Long et al. 2002, Bäckstrand et al. 2017), unions (e.g. Räthzel and Uzzell 2013) and even individuals (e.g. Rowlands 1995). However, little systematic research has been conducted on subnational and non-state actors as leaders or pioneers. This Volume aims to make a contribution towards closing this research gap.

\section{Multilevel governance and polycentricity}

In contemporary climate governance scholarship, increasing attention is being paid to a wider range of governance actors and levels, including the international, supranational, transnational, national and subnational levels. Multilevel governance (MLG) and polycentric 
governance perspectives have become widely used to analyse climate governance (e.g. Jordan et al. 2018). This development has been partly driven by the shift away from a topdown climate governance approach embodied in the 1997 Kyoto Protocol, which stipulates legally binding targets and timetables, and towards a bottom-up approach embodied in the 2015 Paris Agreement, which relies instead on voluntary pledges (so-called Nationally Determined Contributions, NDCs). According to Oberthür (2016, p. 81), the Paris 'Agreement recalibrates the role of the multilateral UN process as providing overall direction towards global decarbonisation, while leaving implementation to other international organisations, states and various non-state actors and initiatives'. Similarly, Jordan and colleagues (2018b, p. 4) have argued that developments in climate change governance since the 2000s 'appear to confirm the trend towards greater polycentricity' which requires the mobilisation of a wider range of non-state actors.

Polycentric governance concepts share certain core presuppositions (e.g. multiple centres of authority and levels of governance) with MLG approaches, although conceptually they are not identical (e.g. Homsy and Warner 2014, Wurzel et al. 2017a, Jordan et al. 2018). By comparison with polycentric governance approaches, MLG concepts normally assume a stronger role for governmental (i.e. state, supranational and sub-national) actors (Morrison et al. 2017, Liefferink and Wurzel 2018). Most MLG-inspired EU studies - for which the MLG concept was initially developed (e.g. Marks 1993, Hooghe 1996) - emphasise the mutual dependency of supranational and subnational governmental actors. Many MLG concepts reject the idea of traditional top-down government in favour of less hierarchical governance which assumes that 'non-state actors co-govern along with state actors for the provision of collective goods and adopt governance functions that have formerly been the sole authority of sovereign states' (Stephenson 2013, p. 829).

Polycentric governance concepts, on the other hand, attribute a high degree of autonomy to societal actors (e.g. business, NGOs and individual citizens). Polycentric approaches claim that widespread self-coordination leads to a multitude of decision-making 'centres' particularly at the subnational level or even at the level of firms (see Bach, Biedenkopf et al., Dupius and Schweizer, Eikeland and Skjaerseth, all this Volume). From a polycentric governance perspective, such self-coordination, which could be conceptualised as leadership/pioneership by societal actors within relatively autonomous policy domains, is essential for the successful functioning of global climate governance (e.g. Ostrom 2012, 
2014, Jordan et al. 2018). According to Dorsch and Flachsland (2017) one of the advantages of polycentric governance is that experimentation at local and decentralised levels may lead to learning-by-doing and subsequent horizontal diffusion or upscaling to higher climate governance levels (see Ostrom 2012, 2014, Kern, this Volume).

Broadly speaking, it could be argued that proponents of polycentricity favour societal self-coordination within market-like governance structures (e.g. Ostrom 2012, 2014) while MLG advocates support the creation of networks in which governmental actors (including supranational EU actors) play an important, if not dominant, role to correct negative market externalities (e.g. Marks 1993, Hooghe 1996, Homsy and Warner 2014). This also has consequences for the conceptualisation of leadership and pioneership. From a polycentric governance perspective, in principle any successful self-coordination or experimentation at any governance level could be seen as pioneership. Polycentricity can help us understand why and how such initiatives emerge and flourish (Dorsch and Flachsland 2017, Jordan et al. 2018). However, due to the relative autonomy of polycentric sub-systems, the number of potential followers may be limited (Liefferink and Wurzel 2018). For the wider leader/pioneer-follower dynamic the overarching MLG context in which polycentric systems may be embedded is important (Morrison et al. 2017).

Within the broader context of MLG and polycentric approaches, we provide a critical assessment of the climate leader and pioneer literature. We do so by proposing answers to the following core research questions: (1) Who can be a leader/pioneer?; (2) Why do actors become leaders/pioneers?; (3) How do leaders/pioneers act?; and (4) How do leaders/pioneers attract followers? Some of these questions have been addressed by earlier studies, but not in a specifically MLG and polycentric governance context. In particular, by focusing on the EU, business and subnational actors (including cities) as potential leaders and pioneers, the contributions to this Volume provide new answers to the who, why and how questions of leadership and pioneership. Moreover, the focus on followership opens a new dimension to the leadership/pioneership literature. By focusing on agents of change (i.e. leaders and pioneers), we draw heavily on actor-focused approaches (which are compatible with MLG and polycentric governance concepts) although we do not ignore structural factors (e.g. structural leadership).

\section{Who can be a leader or a pioneer?}


Although states, IOs, the supranational EU, subnational actors and societal actors have all been identified as potential environmental leaders or pioneers, the early climate governance literature focused primarily on states. However, competing conceptual approaches have emphasised the relative importance of particular types of actors who, as will be explained below, may offer different types of leadership/pioneership and followership.

State-centred approaches still dominate both international relations (IR) and comparative politics (CP) research on environmental/climate leaders and pioneers. The early IR literature focused on the leading role of states in international environmental/climate regimes (e.g. Young 1991, Underdal 1994) while CP studies have assessed the political characteristics and institutional capacities of states which transform into environmental leaders/pioneers (e.g. Jänicke and Weidner 1997, Weidner et al. 2002). In contrast to international regimes, IOs have been seen as being capable of exhibiting independent 'actorness' capabilities at least in institutionalist approaches. The OECD's successful efforts in diffusing the polluter pays principle constitutes a relevant example of IO environmental leadership (OECD 1975).

Single country studies differentiated early on between internal and external (i.e. domestic and foreign) environmental/climate policy ambitions (e.g. Prittwitz 1984). For example, for much of the 1970s/80s, the USA acted as an environmental leader on both the domestic and international levels (e.g. Rowlands 1995), while Japan's progressive domestic environmental policy was not matched by similarly high international ambitions (e.g. Imura and Schreurs 2005). Importantly, CP state-centred and single country studies initially focused exclusively on highly developed liberal democracies. The transitional Central and Eastern European states (CEES), rapidly developing countries and developing countries were initially not seen as capable of exhibiting environmental/climate leadership/pioneership, although this view is gradually being challenged (e.g. Torney 2015, Wurzel et al. 2017a).

The $E U$ seems to have provided particularly fertile ground for climate leadership/pioneership (e.g. Grubb and Gupta 2000, Oberthür and Roche Kelly 2008, Jordan et al. 2010, Torney 2015, Wurzel et al. 2017a, see also Jänicke and Wurzel, this Volume). Schreurs and Tiberghien (2007) have argued that the EU's climate policy-making processes provide multilevel reinforcement mechanisms which can trigger the ratcheting upwards of the environmental standards set by the leaders or pioneers (see already Rehbinder and Stewart 1985). From the early 1980s to the mid-1990s, the so-called green troika - Germany, 
the Netherlands and Denmark - acted as a major driver for EU environmental policy development. The EU accession by Sweden, Finland and Austria in 1995 transformed the green trio into a green sextet and triggered a more systematic investigation of environmental leaders and pioneers and their impact (e.g. Héritier 1996, Andersen and Liefferink 1997, Liefferink and Andersen 1998, Börzel 2002, Wurzel 2008).

Within the climate leadership/pioneership literature the sub-national level attracted scholarly attention only at a relatively late stage although there are exceptions (e.g. Freeman 1996, Bulkeley and Betsill 2005, Eckersley 2018, see also Kern, this Volume). One reason for the belated scholarly focus on subnational climate leadership is the strong initial focus of the social science literature on the international climate negotiations. As these negotiations became more protracted over time the scholarly search for evidence of climate leadership/pioneership shifted from the international level to the national and subnational levels (e.g. Wurzel et al., this Volume). Jänicke (2014, p. 43) has argued that the local level is a late mover in the process of climate policy, but has become the most dynamic driver of technical change towards a low-carbon energy system'.

Business is important for developing technological innovations and creating 'green' markets (e.g. Jänicke and Jacob 2002). However, businesses operating in jurisdictions with high regulatory standards may also have a more direct influence on policy by promoting the adoption of stringent standards at the international and/or supranational level for reasons of competitiveness (e.g. Vogel 1997, Liefferink and Wurzel 2018, Dupuis and Schweizer, this Volume). In addition to that, business has frequently propagated the adoption of voluntary agreements and 'self-regulation' which theoretically fits polycentric approaches. However, business often 'remains the elephant in the room or perhaps just outside the door' (Grant 2011, p. 212) when it comes to the adoption of ambitious climate governance measures. This can be seen, for example, in the German automobile industry's resistance to more ambitious EU standards for carbon dioxide $\left(\mathrm{CO}_{2}\right)$ in the 2010s. As the literature remains ambivalent on whether business can effectively act as a climate leader or pioneer, this Volume pays particular attention to the ability and/or willingness of business to offer climate leadership/pioneership (see Bach, Biedenkopf et al., Dupuis and Schweizer, Skjaerseth and Eikeland, all this Volume).

Environmental NGOs (ENGOs) are widely recognised as important climate governance actors because they can help to raise public awareness, shape or even set the 
agenda and monitor adopted domestic policies and/or international treaties (e.g. Long et al. 2002, Bäckstrand et al. 2017). NGOs with a large membership/supporter base can generate additional legitimacy for governmental actors who are keen to show climate leadership/pioneership often against resistance from other actors such as business (Wurzel et al. 2017b).

Trade unions are somewhat less prominent climate governance actors. According to Räthzel and Uzzell (2013, p. 5), 'new movements in the trade union movements' have shown 'a concern for nature by taking on climate change as an issue of trade union politics'. In particular unions in highly affluent countries have long campaigned for more ambitious environmental and health standards, often through seeking to combine environmental concerns with traditional trade union objectives through concepts such as 'climate justice' which are usually supported also by ENGOs.

Scientists (e.g. Rowlands 1995) and epistemic communities (e.g. Haas 1992) have played a more prominent role as climate leaders or pioneers. Although scientific insights are crucial for both the recognition of problems and for solving them, Underdal $(2000, p$. 3) has argued that 'adequate knowledge about the problem itself and available response options is a necessary - although by no means a sufficient - condition for designing and operating effective international regimes' while also flagging up that 'policy cannot simply be derived from knowledge, however firm the knowledge base may be' Underdal (2000, p. 5).

One should not underestimate the role of individuals - such as Al Gore or Laurent Fabius - in raising awareness, instigating climate governance action or competently chairing international negotiations. As Parker and Karlsson (2014, p. 582) have argued '[t]he focus on collective entities as the main unit of analysis [in many leadership studies] does not [...] mean that individuals should be taken out of the equation'. Although some environmental governance studies have flagged up the importance of individuals in international climate change politics (e.g. Rowlands 1995), the leadership/pioneership capabilities of individuals at different climate governance levels remains under-researched.

There is, however, an extensive urban studies literature which identifies climate leadership/pioneership and entrepreneurship by individuals as being centrally important for local climate governance (e.g. Bulkeley and Betsill 2005, Jonas et al. 2011, Eckersley 2018, see also Kern and Wurzel et al., both this Volume). 
This Volume is not able to assess whether all of the above mentioned types of actors have indeed been able to act as leaders and/or pioneers in climate governance. Instead its focus will be mainly on the EU (see Jänicke and Wurzel, this Volume), corporate actors (see Biedenkopf et al., Dupius and Schweizer, Bach, and Eikeland and Skjærseth, all this Volume) and cities (see Kern and Wurzel et al., both this Volume).

\section{Why a leader/pioneer?}

The question of why an actor tries to become an environmental leader or pioneer has been variously answered. Much of the state-centred CP literature has focused on a wide variety of structural factors underlying the ambitions and motivations of environmental leaders and pioneers. A high level of environmental problem pressure, high political salience of environmental issues and regulatory competition are seen as important drivers for the emergence of environmental leaders and pioneers (e.g. Weidner et al. 2002, Jänicke and Jacob 2002, Liefferink et al. 2009). There is, however, often also a normative dimension which must be considered when identifying and assessing environment leaders and pioneers. For example, while nuclear power has been advocated by some states (e.g. France) as part of the solution to reduce greenhouse gas emissions, other states (e.g. Germany) have decided to phase out nuclear power in favour of renewable energy.

The environmental capacity literature has identified, among others, institutional, politico-administrative, informational-cognitive and technological capacities as core drivers of leadership/pioneership from states (e.g. Jänicke 2006). Other important explanatory factors for countries exhibiting a high level of environmental capacity include EU membership (e.g. Jänicke and Jacob 2002, Liefferink et al. 2009), corporatism (e.g. Crepaz 1995), high levels of economic affluence (e.g. Börzel 2002) as well as a wide range of issue and/or context specific factors (e.g. Jänicke and Weidner 1997, Liefferink et al. 2009).

Whether the same or similar factors which help to explain climate leadership/pioneership by states also apply to sub-national and non-state actors (such as cities or business) is still an unresolved question, which the contributions in this Volume address. Broadly speaking, the MLG literature emphasises the role of supranational and subnational actors in addition to state actors (e.g. Fairbrass and Jordan 2004, Jordan et al. 2010) while the polycentric climate governance literature focuses largely on societal actors (e.g. Ostrom 2012, 2014, for critical reviews see e.g. Jordan et al. 2015, 2018, Morrison et al. 
2017). High environmental problem pressure, high political salience of environmental issues and regulatory competition are likely also to affect non-state actors. Creating and maintaining a green public image appears to be increasingly important for cities (e.g. Kern and Bulkeley 2009, Jonas et al. 2011, Eckersley 2018). The EU's annual European Green Capital Award and the European Energy Award are used as marketing tools by the holders (see Kern and Wurzel et al., both this Volume). Important drivers for environmental innovations from business include pressure from environmentally concerned consumers and the creation of 'green' lead markets which can give 'green' companies a competitive advantage (e.g. Jänicke and Jacob 2002, see also Skjaerseth and Eikeland, Dupuis and Schweizer, both in this Volume).

Another way of looking at why actors strive to become leaders or pioneers is to investigate the way their 'green' ambitions are structured. While drawing on the above mentioned distinction between leaders and pioneers, we assess four possible combinations of an actor's internal and external ambitions (Prittwitz 1984, Liefferink et al. 2009, Liefferink and Wurzel 2017) on a scale which ranges from 'low' to 'high' (see Table 1). Although the analytical distinction between internal and external 'green' ambitions was originally developed only for states (Liefferink and Wurzel 2017), in this contribution we extend it also to non-state actors.

Table 1: Internal and external environmental ambitions of actors, leading to four idealtypical positions

\begin{tabular}{|l|l|l|}
\hline & Internal environmental ambitions \\
\hline External environmental & Low & High \\
ambitions & & (b) Pioneer \\
\hline Low & (a) Laggard & (d) Substantive leader: \\
\hline High & (c) Symbolic leader & $\begin{array}{l}\text {-Constructive pusher } \\
\end{array}$ \\
& & -Conditional pusher \\
\hline
\end{tabular}

Source: Adapted from Liefferink and Wurzel (2017). 
Table 1 distinguishes in ideal-typical fashion between the following four positions: (a) Low internal and low external ambitions lead actors to become laggards (or, at best, followers); (b) the combination of high internal and low external ambitions turns actors into pioneers which try to 'go it alone' in particular if they consider themselves constrained by followers or laggards; (c) low internal and high external ambitions turn actors into symbolic leaders which fail to back up their externally directed green ambitions with internal actions; (d) the combination of high internal and high external ambitions turns actors into substantive leaders which seek others to adopt the same or at least similar ambitions. The analytical term substantive leader acts as an umbrella term which subsumes constructive and conditional pushers. While constructive pushers adopt unconditionally (i.e. unilaterally) ambitious internal environmental measures, conditional pushers take ambitious internal measures only if other actors adopt similar measures. The main reason for this is that conditional pushers are often concerned about the potentially negative economic impact which unilaterally adopted environmental standards may have. For a constructive pusher, environmental ambitions override economic concerns. The bottom row of Table 1 depicts the two possible cases of high external ambitions which can be associated with leadership although symbolic leaders fail to back up their high external ambitions with high internal ambitions which stands in contrast to substantive leaders (which encompass constructive and conditional pushers).

Pioneership/leadership refers either to actors who are the first to introduce and/or propagate a certain policy measure or those who exhibit the highest level of ambition. Being 'the first in class' and being 'the best in class' may not necessarily go together. In fact, the initial leader or pioneer can be overtaken by followers who may adopt even higher ambitions (e.g. Burns 2003, Liefferink and Wurzel 2017).

\section{How do leaders/pioneers act?}

Leaders and pioneers may exert leadership in various ways. Building in particular on Young (1991), Liefferink and Wurzel (2017) and Wurzel et al. (2017a), we distinguish the following four types of leadership(1): (1) structural leadership, (2) entrepreneurial leadership, (3) cognitive leadership, and (4) exemplary leadership. As will be explained below, leaders can make use of all four types of leadership while pioneers are likely to offer primarily exemplary 
'pioneership' by setting unintentionally a good example without having the explicit intention of attracting followers.

First, structural leadership has traditionally been associated with military power especially by realist IR scholars (e.g. Waltz 1979). However, structural leadership has also been linked to economic power (e.g. Nye 2008). While few non-state actors (e.g. terrorist movements) possess military power, economic power can be widely found amongst non-state actors including in particular business (e.g. the capacity to create jobs) but also NGOs (especially if they have a large membership base) and consumers (e.g. purchasing power). Importantly, although structural leadership and power are closely related concepts, they are not identical (Young 1991, Nye 2008). Oberthür (2016, p. 83) has argued that '[p]ower and power structures have become an increasingly prominent consideration in analyses of international climate policy in the $21^{\text {st }}$ century' while pointing out 'the rise of climate change to high politics, great power politics and even geopolitics as well as the rise of emerging powers'.

Burns' (1978, p. 19) argument that '[a]ll leaders are actual or potential power holders, but not all power holders are leaders' helps to explain why not all powerful states (e.g. the US and China at various points in time) exhibit structural leadership in international climate governance. Power, in other words, is a necessary but not a sufficient condition for structural leadership. An actor possessing power becomes a structural leader only by mobilising its structural power in pursuit of collective goods. Morrison et al. $(2017$, p. 2) have criticised proponents of polycentricity for inadvertently rendering polycentrism as power-free because they ignore 'not only different types of power at play but also how their distribution may affect both governance processes and environmental outcomes'. Similarly, Singleton (2017, p. 1000) has argued '[p]ower is a concept that remains largely underdeveloped within Ostrom's work rendering her themes "curiously apolitical" (Wall, 2014, p. 480)'. MLG on the other hand often adopts a 'top-down view of subnational actors' (Fairbrass and Jordan 2004, p. 152) according to which supranational actors have greater decision-making powers despite the mutual dependencies which exists between them and subnational governance actors. In other words, MLG concepts assume that 'supranational actors play a decisive and proactive (i.e. entrepreneurial) rather than a subordinate role, in EU policy-making' (Fairbrass and Jordan 2004, p.151). 
In addition to military and economic power, an actor's relative contribution to a particular environmental problem and/or its ability to offer solutions may also provide it with structural power. For instance, because China has been responsible for about 30 percent of the world's $\mathrm{CO}_{2}$ emissions since the early 2010s it gained systemic relevance for and considerable structural power in international climate change politics. Similarly, business actors (e.g. the oil industry and wind energy sector) derive structural power from their relative contribution to the problem as well as their 'low-emission capacity', defined by Oberthür (2016, p. 85) as the 'ability to contribute to and benefit from the move to decarbonisation' (see also Bach, this Volume).

Secondly, entrepreneurial leadership involves the use of diplomatic and/or negotiating skills with a view to brokering compromises and agreements (Young 1991). An entrepreneurial leader is usually 'an agenda setter and popularizer who uses negotiating skill to devise attractive formulas and to broker interests' (Young 1991, p. 300). Entrepreneurial leadership may be employed by a wide range of state and non-state actors such as businesses and NGOs. Polycentric concepts focus largely on site-specific conditions to assess 'the specific capabilities of individual actors and their potential to cooperate' (Dorsch and Flachsland 2017, p. 52). They tend to emphasise the importance of self-organisation in policy domain specific, decentralised decision-making system (Ostrom 2012, 2014). MLG concepts also reject the idea of a single or even central point of steering in terms of climate governance (Jordan et al. 2012, p. 52). Both polycentric and MLG concepts therefore refute the idea of monocentric governance. However, while MLG concepts emphasise the importance of 'baton passing' by environmental leaders/pioneers and 'multilevel reinforcement' by supranational actors for climate governance innovations to become sustainable (Schreurs and Tiberghien 2007), polycentric concepts argue that the emergence of self-organised cooperation as well as innovative experimentation and learning is most likely to emerge in decentralised, site-specific domains in which trust is high.

Thirdly, cognitive leadership involves defining or redefining ideas and concepts such as ecological modernisation, which postulates that ambitious environmental/climate measures may also benefit the economy, e.g. in form of the 'green' or low carbon economy. It may also relate to cause-effect relations and policy solutions through the provision of scientific and experiential knowledge regarding innovative climate measures (Haverland and Liefferink 2012). A wide range of actors (e.g. states, research institutes, business and NGOs) 
may be able to offer cognitive leadership. Such actors can form networks and epistemic communities (e.g. Haas 1992) which may enhance the cognitive leadership potential of actors. Both MLG and polycentric approaches consider 'the plurality of actors and levels and the complexity of their interactions not as obstacles but as an opportunity for innovation and interactive learning' (Jänicke 2017, p. 118, see also Marks and Hooghe 2004, p. 16, Ostrom 2012, 2014). Ostrom (2014, p. 119) has advocated the adoption of 'a polycentric approach to the problem of climate change in order to gain the benefits at multiple scales as well as to encourage experimentation and learning from diverse policies adopted at multiple scales'. Similarly, Marks and Hooghe (2004, p. 16) argued that MLG structures 'facilitate innovation and experimentation'.

While powerful actors (e.g. large states and businesses) find it easier to acquire structural leadership capabilities than less powerful actors (e.g. small states and small cities), this is not necessarily the case for cognitive leadership capabilities. For example, some of the small EU member states (e.g. Denmark and the Netherlands) have been able to provide considerable cognitive leadership for EU environmental policy over a long period of time (e.g. Andersen and Liefferink 1997). From a cognitive leadership perspective it is therefore not surprising that the polycentricity as well as the urban governance literature have flagged up the importance of cities and regions as laboratories for experimentation and sources of innovation (e.g. Bulkeley and Betsill 2005, Ostrom 2012, 2014). Subnational or regional actors have also been identified as important environmental innovators by the MLG literature (e.g. Fairbrass and Jordan 2004).

Fourthly, exemplary leadership (or leadership by example) refers to the intentional setting of examples for others while unintentional example setting is referred to as exemplary pioneership in this contribution and throughout the Volume. Intentional exemplary leadership resembles what Grubb and Gupta (2000) have defined as directional leadership. Intentional exemplary leadership and directional leadership amount to a constructive pusher position (see Table 1). Constructive pushers intentionally put forward domestic policies as models for others. Unintentional example-setting, in contrast, refers to pioneers who do not seek to attract followers. Exemplary leadership/pioneership may be offered by state actors (e.g. national and subnational local governments) as well as non-state actors (e.g. business and NGOs, see Biedenkopf et al., this Volume). Exemplary leadership/pioneership plays an important role for both MLG and polycentric governance 
concepts which pay particular attention to innovations by actors at 'lower' governance levels while arguing that they can be up-scaled to 'higher' governance levels (e.g. Schreurs and Tiberghien 2007, Ostrom 2012).

Importantly, leaders can and usually do combine different leadership types (Young 1991, Parker and Karlsson 2014, p. 586, Wurzel et al. 2017). A leader can, for instance, simultaneously exert entrepreneurial leadership through coalition-building around a particular issue, cognitive leadership by supporting these efforts with scientific evidence, and exemplary leadership by acting as a model for others. The specific mix of different types of leadership employed by a particular actor, as well as the different ways in which they may interact varies across issues and may evolve over time (Liefferink and Wurzel 2017, see also the other contributions, this Volume).

Burns' $(1978,2003)$ differentiation between transactional and transformational leadership has been relatively widely used in the environmental/climate governance literature (e.g. Liefferink and Wurzel 2017, Morrison et al. 2017, Wurzel et al. 2017a). Transactional leadership typically refers to low ambitions over a relatively short time horizon. In contrast, transformational leadership aims at profound or even 'revolutionary' changes. These can usually be achieved only over a relatively long time horizon (cf. Burns 1978). However, 'revolutionary' leadership may also occur on a much shorter time scale. Germany's energy transition (Energiewende), which demands the replacement of nuclear power by primarily renewable energy within a relatively short time period, is a fitting example. Furthermore, as Burns $(1978,2003)$ has pointed out, transactional leadership extending over an extremely long timescale may eventually trigger transformational change.

Differentiating between the degree of ambition and timescale allows for a more finegrained analysis of leaders and pioneers. Whether it is applicable not only to state but also to non-state actors is assessed in the contributions to this Volume. For example, Biedenkopf et al. and Dupuis and Schweizer (both this Volume) show that highly innovative firms may have far-reaching internal ambitions in the short term while their external leadership ambitions are followed up over a much longer time scale.

\section{Followers and followership}

Compared with the extensive literature on environmental/climate leadership/pioneership reviewed above, scholars have paid much less attention to followers and followership, 
although notable exceptions exist (e.g. Torney 2014, 2015, for the general literature on leaders and followers see Rhodes and t'Hart 2014). This is perhaps understandable given the methodological and evidential challenges associated with convincingly identifying followers and followership. Much of the policy transfer and learning literature acknowledges that it is generally easier to identify actors who come up with policy innovations (i.e. act as their source) rather than to identify actors who emulate the leaders/pioneers and the mechanisms through which such emulation takes place (e.g. Tews et al. 2003). In order to convincingly identify followership, we must not only identify a purported leader/pioneer and an actor that has adopted similar policies or responses, but also prove that the leader/pioneer and follower are causally linked.

As Rhodes and t'Hart (2014: 6) have pointed out ' $[t]$ here is now a growing body of thought and research that understands leadership as an interactive process between leaders and followers'. Followership is crucial in MLG and polycentric climate governance. However, polycentric governance approaches generally assume relatively high levels of autonomy of actors within and between polycentric governance systems (see above). At first sight, leaderfollower relationships seem much more likely to emerge within rather than between sitespecific polycentric governance domains. However, as argued above, polycentric governance actors may still function within an overarching MLG context (Liefferink and Wurzel 2018). Furthermore, even if actors within polycentric governance systems enjoy considerable levels of formal autonomy, their relationships with other actors may nonetheless be characterised by interconnectedness, providing opportunities for the emergence of leader-follower dynamics. Morrison et al. (2017, p. 2) have defined a polycentric system as 'made up of many autonomous units that are formally independent of one another but which chose to act in ways that take account of others through self-organized processes of cooperation and conflict resolution'. Nevertheless, pioneers, who do not intentionally set out to gain followers, should be more prevalent than leaders in polycentric governance systems, which are characterised by relatively autonomous market-like or self-organising decision-making structures (Liefferink and Wurzel 2018). Why and how pioneers may unintentionally and leaders intentionally attract followers is well covered in the policy transfer, diffusion and learning literature (e.g. Tews et al. 2003, see also Jänicke and Wurzel, this Volume).

An attempt to conceptualise followership poses a number of questions (see Torney, this Volume). First, who follows? In principle, followers can emerge in response to leaders in 
all of the categories of actors set out above: states, supranational and subnational actors, businesses, NGOs, trade unions, scientists and individuals. In order to count as followership, the follower must in some meaningful way adopt the same or a substantively similar approach to a particular climate/environmental problem. This limits the potential for leaderfollower dynamics that cut across actor categories, and makes within-actor category leaderfollower dynamics (e.g., state-state, business-business, NGO-NGO) more likely. The success of a social enterprise such as FairPhone in providing exemplary leadership for other corporations could be considered as followership on the part of those other corporations, though as Biedenkopf et al. show in their contribution to this Volume, structural constraints limit the possibility of such followership materialising. Wurzel et al. (this Volume), who assess whether structurally disadvantaged cities can act as leaders/pioneers or merely as followers of more affluent leader cities, argue that even for the same type of actor (i.e. cities) further differentiation may be necessary to establish the dynamics of leader/pioneerfollowership relations. This can only be done through contextualised empirical research.

Different theoretical approaches provide different perspectives on the potential for leader-follower relationships across actor categories. For state-centric approaches, normally only state actors (i.e. 'within-category' actors) are able to enter into analytically meaningful leader-follower relations. By contrast, polycentric governance approaches allow for leaderfollower relations between potentially all actor categories (e.g. individuals, businesses, NGOs and state actors). Meanwhile, MLG concepts focus on leader-follower relations at different governance levels and usually emphasising the role of public actors such as state, supranational and subnational actors. MLG concepts therefore arguably sit somewhere in between polycentric and state-centric concepts as regards analytically meaningful leadership-followership relations. However, as discussed above, some variants of MLG concepts are quite close to polycentric concepts as regards the importance which they attach to non-state actors as governance actors.

A second question concerns the pathways through which the leader-follower dynamic plays out. Followership can emerge in a variety of ways and for different reasons. It is helpful to distinguish between followership that springs from a logic of consequences and a logic of appropriateness (March and Olsen 1998). This also, to some extent, maps on to the types of leadership identified above. Drawing on a logic of consequences, followers may be induced to follow structural leadership through material incentives that alter their cost- 
benefit calculations. Taking a logic of appropriateness perspective, by contrast, followership can materialise through learning and emulation, including new ideas promulgated by cognitive leaders or from exemplary leaders who are perceived to provide innovative solutions. In such cases, followers follow leaders not because they are incentivised to do so, but because they believe the models provided by a leader to be superior in some way and worthy of followership. Followership on the basis of both a logic of consequences and a logic of appropriateness, furthermore, may be supported by entrepreneurial leadership.

A third question concerns the conditions under which leaders attract followers. Relevant factors can be identified with respect to both the leader and the purported follower. Again, it is helpful to distinguish between a logic of consequences and a logic of appropriateness. In the case of the leader-follower dynamic with respect to structural leadership (logic of consequences), the source of structural power matters, as does the degree of power asymmetry between the leader and follower (see Morrison et al. 2017). Economic power due to strong market asymmetries may give other actors little choice but to follow (although structural leadership usually does not amount to outright coercion which would leave no options to other actors but to follow the leader), whereas less asymmetric and/or symmetric market-like relations are likely to give purported followers considerably more leeway to pursue alternative options. In the case of a logic of appropriateness, the perceived legitimacy of an exemplary or cognitive leader is likely to be critical. Does the leader follow up its external ambitions by internal actions or is its leadership perceived to be merely symbolic, and are the models and knowledge provided by the purported leader viewed as authoritative (Parker and Karlsson, 2010)? The extent to which the idea/approach being promulgated by the leader resonates with pre-existing domestic norms and beliefs of the follower, and the extent to which the leader has sought, by way of cognitive leadership, to build congruence between new and pre-existing norms and beliefs are also likely to be important (e.g. Checkel 2005).

The questions of who follows, through what pathways, and under what circumstances are followers likely to follow provide a roadmap for developing systematic research on the under-researched leader/pioneer-follower relationship. Pursuing answers to these questions allows us to fill a gap in the literature (see Torney, this Volume).

\section{Conclusion}


States are no longer, if they ever were, seen as the only actors capable of acting as climate leaders/pioneers (e.g. Young 1991, Underdal 1994, Wurzel et al. 2017a). A wide range of sub-national and non-state actors (e.g. cities and businesses) have also been identified as putative agents of change. Importantly, climate leaders or pioneers often must act (either simultaneously or sequentially) at different levels of climate governance to be able to achieve their internal and/or external ambitions and, in the case of leaders, to attract followers.

State-centred, MLG and polycentric governance concepts place different emphasis on the roles played by different types of leadership/pionieership in climate governance. Although the differences between these three conceptual perspectives should not be exaggerated, it seems clear that state-centred theories (especially in the IR literature) attach proportionately greater emphasis to state actors and inter-state relations. Without downplaying the role of cognitive, entrpreneurial and exemplary leadership in such relations, a state-perspective is likely to pay particular attention to structural leadership. MLG concepts emphasise the importance of supranational EU and sub-state actors and their network-like relationships which stretch across different levels of governance and require in particular entrepreneurial leadership although attention is usually also paid to structural, cognitive and exemplary leadership. Polycentric governance approaches argue that successful climate governance depends largely on the existence of strong relatively autonomous decentralized and/or local decision-making centres which allow for societal self-coordination or even self-governing under conditions of trust. Polycentric settings thus encourage experimentation and learning-by-doing, i.e. cognitive and exemplary leadership, which, if successful, can be scaled up in a bottom-up fashion to other actors or higher levels of climate governance. Polycentric governance approaches arguably pay least attention to structural leadership.

Why actors develop into climate leaders/pioneers depends on their internal and external ambitions as well as on a set of more structural drivers including problem pressure, the political/public salience of climate change and competitive pressures which need to be established empirically. Our Introduction has differentiated between structural, entrepreneurial, cognitive and exemplary leadership/pioneership which are assessed in the contributions that follow in this Volume. The analytical differentiation into different types of leadership/pioneership helps to explain why some actors which have relatively little 
structural power may nevertheless become relatively influential climate governance actors capable of showing leadership or pioneership. The reason for this is that such actors may be able to compensate at least partly for their lack of structural leadership capacity with entrepreneurial and/or cognitive leadership/pioneership.

Whether leaders attract followers has, to a certain extent, been the 'poor relation' in the literature. While polycentric governance concepts focus strongly on 'between category' leader-follower relations, state-centric and MLG concepts assume that followers primarily emerge in response to leadership by actors from the same actor category. In other words, within-category leader-follower relationships are most likely while between-category 'leader-follower' like relations are conceptually best termed as influence. Within category followership can emerge as a result of power asymmetries (e.g. market asymmetries) or the provision of incentives (logic of consequences), deriving from structural leadership, on the one hand, or the power of attraction (logic of appropriateness), deriving primarily from cognitive and exemplary leadership, on the other.

The other contributions of this Volume focuses in particular on the EU (Jänicke and Wurzel), corporate actors (Biedenkopf et al., Dupius and Schweizer, Bach, and, Eikeland and Skjærseth) and cities (Kern and Wurzel et al.). While all contributions assess leadership and pioneership within MLG and/or polycentric governance systems, Torney's contribution focuses in particular on followers and followership.

\section{Acknowledgements}

The authors are grateful to the Innovations in Climate Governance (INOGOV) programme which funded a workshop on 'Pioneers and Leaders in Polycentric Climate Governance (PiLePoC) in Hull on 15-16 September 2016 at which early versions of contributions in this Volume were presented. Rudi Wurzel would like to thank the British Academy (grant no. SG 131240) and the University of Hull for additional funding. Diarmuid Torney would like to thank Dublin City University for support from the Faculty of Humanities and Social Sciences Journal Publication Scheme. We are very grateful to Louise FitzGerald for extensive editorial assistance for this Special Issue. We are also grateful to the referees for their very helpful comments. The usual disclaimer applies. 


\section{Disclosure statement}

No potential conflict of interest was reported by the authors.

\section{Endnotes}

(1) Many of the early IR leadership studies put forward a threefold typology. For example, Young (1991) drew on structural, intellectual and entrepreneurial leadership while Underdal (1994) referred to coercive, unilateral and instrumental leadership. Malnes (1995) added directional leadership, which amounts to leadership by example, as a fourth analytical category (see also Grubb and Gupta 2000 and Parker and Karlsson 2010 and 2014).

\section{References}

Andersen, M.S. and Liefferink, J.D., eds. 1997. European environmental policy: The pioneers. Manchester: Manchester University Press.

Bäckstrand, K., Kuypers, W., Linnér, B.-O. and Lövbrand, E. eds 2017. Special Issue: Non-state actors in the new landscape of international cooperation, Environmental Politics, 26 (4).

Börzel, T. A. 2002. Pace-setting, foot-dragging and fence-sitting. Journal of Common Market Studies, 40 (2), 193-214.

Bulkeley, H. and Betsill, M. 2005. Rethinking sustainable cities: multilevel governance and the 'urban' politics of climate change. Environmental Politics, 14 (1), 42-63.

Burns, J.M. 1978. Leadership. New York: Harper \& Row.

Burns, J.M. 2003. Transforming Leadership. New York: Grove Press.

Checkel, J.T. 2005. International institutions and socialization in Europe: Introduction and framework'. International Organization. 59 (4), 801-26.

Crepaz, M., 1995. Explaining national variations of air pollution levels. Environmental Politics, 4 (3), 391-414.

Dorsch, M.J. and Flachsland, C. 2017. A polycentric approach to global climate governance. Global Environmental Politics, 17 (2), 45-64.

Eckersley, P. 2018. Who shapes local climate policy? Unpicking governance arrangements in English and German cities, Environmental Politics, 27 (1), 139-60. 
Fairbrass, J. and Jordan, A. 2004. Multi-level governance and environmental policy. In: I. Bache and M. Flinders, eds. Multi-level governance. Oxford: Oxford University Press, 147-64.

Freeman, C. 1996. Local government and emerging models of participation in the Local Agenda 21 process. Journal of Environmental Planning and Management. 39 (1), 6578.

Grant, W. 2011. Business: The elephant in the room. In: R.K.W. Wurzel and J. Connelly, eds. The European Union as a Leader in International Climate Change Politics, London: Routledge, 197--213.

Grubb, M. and Gupta, J. 2000. Climate Change, Leadership and the EU. In: J. Gupta and M. Grubb eds., Climate Change and European Leadership. Dordrecht: Kluwer Publishers, 3-14.

Haas, P.M. 1992. Introduction: epistemic communities and international policy coordination. International Organization, 46 (1), 1-35.

Haverland, M. and Liefferink, D. 2012. Member State interest articulation in the Commission phase. Journal of European Public Policy, 19 (2), 179-97.

Héritier, A. 1996. The accommodation of diversity in European policy-making and its outcomes: regulatory policy as a patchwork. Journal of European Public Policy, 3 (2): 149-67.

Homsy, G.C. and Warner, M.E. 2014. Cities and Sustainability: Polycentric Action and Multilevel Governance. Urban Affairs Review, 49 (1), 1-28.

Hooghe, L. ed. 1996. Multi-level Governance and European Integration. Oxford: Clarendon Press.

Imura, H., and Schreurs, M.A. eds. 2005. Environmental Policy in Japan. Cheltenham: Edward Elgar Publishing.

Jänicke, M. 2006. Trend Setters in Environmental Policy: The Character and Role of Pioneer Countries. In: M. Jänicke and K. Jacob eds. Environmental Governance in Global Perspective. Berlin: Environmental Policy Research Centre, 51-66.

Jänicke, M. 2014. Multi-level Reinforcement in Climate Governance. In: A. Brunnengräber and M.A. Di Nucci eds., Im Hürdenlauf zur Energiewende. Berlin: Springer, 35-47.

Jänicke, M. 2017. The multi-level system of global climate governance - the model and its current state. Environmental Policy and Governance, 27, 108-121. 
Jänicke, M. and Jacob, K. 2002. Ecological Modernisation and the Creation of Lead Markets. FFU Report 02-03, Berlin: Environmental Policy Research Centre.

Jänicke, M. and Weidner, H. 1997. National Environmental Policies. Berlin: Springer.

Jonas, A.E.G., Gibbs, D. and While, A. 2011. The new urban politics as a politics of carbon control, Urban Studies 48, 2537-2544.

Jonas, A.E.G, Wurzel, R.K.W., Monaghan, E. and Osthorst, W. 2017. Climate change, the green economy and re-imagining the city: the case of structurally disadvantaged European maritime port cities. Die Erde, 148 (4), 197-211.

Jordan, A., Huitema, D. van Asselt, H., Rayner, T. and Berkhout, F. eds. 2010. Climate Change Policy in the European Union. Cambridge: Cambridge University Press.

Jordan, A., van Asselt, H., Berkhout, F. , Huitema, D. and Rayner, T. 2012, Understanding the Paradoxes of Multilevel Governing: Climate Change Policy in the European Union, Global Environmental Change, 12 (2), 43-66.

Jordan, A.J., D. Huitema, M. Hildén, H. van Asselt, T.J. Rayner, J.J. Schoenefeld, J. Tosun, J. Forster and Boasson, E.L. 2015. Emergence of polycentric climate governance and its future prospects. Nature Climate Change 5, 977-982.

Jordan, A., Huitema, D. van Asselt, H. and Forster, J. eds. 2018a. Governing Climate Change: Polycentricity in Action. Cambridge: Cambridge University Press.

Kern, K. and Bulkeley, H. 2009. Cities, Europeanization and multi-level governance: governing climate change through transnational municipal networks. Journal of Common Market Studies, 47 (2), 309-32.

Liefferink, D. and Andersen, M.S. 1998. Strategies of the "green" member states in EU environmental policy-making. Journal of European Public Policy, 5 (2), 254-270.

Liefferink, D., Arts, B., Kamstra, J., and Ooijevaar, J., 2009. Leaders and laggards in environmental policy. Journal of European Public Policy, 16 (5), 677-700.

Liefferink, D. and Wurzel, R.K.W. 2017. Environmental leaders and pioneers: Agents of change?'. Journal of European Public Policy, 24 (7), 651-68.

Liefferink, D. and Wurzel, R.K.W. 2018. Leaders and pioneers in polycentric governance. In: A. Jordan et al. eds. Governing Climate Change: Polycentricity in Action. Cambridge: Cambridge University Press, 135-51.

Long, T., Slater, L. and Singer, S. 2002. WWF: European and Global Climate Policy. In: R. Pedler ed., European Union Lobbying. Basingstoke: Palgrave, 87-103. 
Malnes, R. 1995. 'Leader' and 'entrepreneur' in international negotiations: A conceptual analysis', European Journal of International Relations, 1 (1), 87-112.

March, J. G. and Olsen, J.P. 1998. The institutional dynamics of international political orders. International Organization, 52 (4), 943-69.

Marks, G. 1993. Structural Policy and Multi-level Governance in the EC. In: A. Cafruny and G. Rosenthal eds. The State of the European Community, Boulder: Lynne Rienner, 391411.

Marks, G. and Hooghe, L. 2004. Contrasting Visions of Multi-level Governance. In: I. Bache and M. Flinders, eds. Multi-level Governance, Oxford: Oxford University Press, 15-30.

Morrison, T.H., Adger, W.N., Brown, K., Lemos, M.C., Huitema, D. and Hughes, T.P. 2017. Mitigation and adaptation in polycentric systems: sources of power in the pursuit of collective goals, WIREs Climate Change, 7, 1-16, doi: 10.1002/wcc.479.

Nye, J. 2008.The Powers to Lead. Oxford: Oxford University Press.

Oberthür, S. 2016. Reflections on global climate politics post paris: Power, interests and polycentricity. The International Spectator, 51 (4) 80-94.

Oberthür, S. and Roche Kelly, C. 2008. EU leadership in international climate policy: achievements and challenges. The International Spectator, 43 (3), 35-50.

OECD 1975. The Polluter Pays Principle. Definition, Analysis, Implementation. Paris: Organisation for Economic Cooperation and Development.

Ostrom, E. 2012. The Future of the Commons: Beyond Market Failure and Government Regulation. In: E. Ostrom et al. (eds), The Future of the Commons. London: The Institute of Economic Affairs, 68-83.

Ostrom, E. 2014. A polycentric approach for coping with climate change. Annals of Economics and Finance, 15 (1): 97-134.

Parker, C. F. and Karlsson, C. 2010. Climate change and the European Union's leadership moment: An inconvenient truth?. Journal of Common Market Studies, 48 (4), 923-43.

Parker, C. F. and Karlsson, C. 2014. Leadership and International Cooperation. In: R.A.W. Rhodes and P. 't Hart eds. The Handbook of Political Leadership. Oxford: Oxford University Press, 580-94.

Prittwitz, V. von 1984. Umweltaußenpolitik, Frankfurt: Campus Verlag. 
Räthzel, N. and Uzzell, D. 2013. Mending the Breach Between Labour and Nature: A Case for Environmental Labour Studies. In: N. Räthzel and D. Uzzell (eds), Trade Unions in the Green Economy. London: Earthscan, 1-11.

Rehbinder, E. and Stewart, R. 1985. Integration Through Law. Berlin: Walter de Gruyter. Rhodes, R.A.W and 't Hart, P. 2014. Puzzles of Political Leadership. In: R.A.W. Rhodes and P. 't Hart eds. The Handbook of Political Leadership. Oxford: Oxford University Press, 121.

Rowlands, I. 1995. The Politics of Global Atmospheric Change. Manchester: Manchester University Press.

Schreurs, M. A. and Tiberghien, Y. 2007. Multi-level reinforcement: Explaining European Union leadership in climate change mitigation. Global Environmental Politics, 7 (4), 19-46.

Singleton, B.E. 2018. What is missing from Ostrom? Combining design principles with the theory of sociocultural viability, Environmental Politics, 26 (6), 994-1014.

Stephenson, P 2013. Twenty years of multi-level governance. Journal of European Public Policy, 20 (6), 817-37.

Tews, K., Busch, P. and Jörgens, H. 2003. The diffusion of new environmental policy instruments. European Journal of Political Research, 42 (4), 569-600.

Torney, D. 2014. External perceptions and EU foreign policy effectiveness: The case of climate change. Journal of Common Market Studies, 52 (6), 1358-73.

Torney, D. 2015. European Climate Leadership in Question. Cambridge. Massachusetts: MIT Press.

Underdal, A. 1994. Leadership theory: rediscovering the arts of management. In: W.I. Zartman ed., International Multilateral Negotiation. San Francisco: Jossey-Bass, 178197.

Underdal, A. 2000. Science and Politics. In: S. Andresen, T. Skodvin, A. Underdal, and J. Wettestad. ed., Science and Politics in International Environmental Regimes. Manchester: Manchester University Press, 1-21.

Vogel, D. 1997. Trading Up. Consumer and Environmental Regulation in a Global Economy. Cambridge M.A.: Harvard University Press.

Wall, D. 2014. The Sustainable Economics of Elinor Ostrom. London: Routledge.

Waltz, K. 1979. Theory of International Politics, Reading: Addison-Wesley. 
Weidner, H., Jänicke, M., and Jörgens, H. eds. 2002. Capacity building in national environmental policy. Berlin: Springer.

Wurzel, R.K.W. 2008. Environmental Policy: EU Actors, Leader and Laggard States. In: J. Hayward ed., Leaderless Europe. Oxford: Oxford University Press, 66-88.

Wurzel, R.K.W., Connelly, J. and Liefferink, D., eds. 2017a. The European Union in International Climate Change Politics. London: Routledge.

Wurzel R. K.W., Connelly, J. and Monaghan, E. 2017b. Environmental NGOs: pushing for leadership. In: R.K.W. Wurzel, J. Connelly and D. Liefferink, eds. The European Union in International Climate Change Politics. London: Routledge, 221-236.

Young, O.R. 1991. Political leadership and regime formation: on the development of institutions in international society. International Organization, 45 (3), 281-308.

Young, O.R. 1999. Regime effectiveness: Taking stock, In: O.R. Young ed., The effectiveness of international environmental regimes, Cambridge, Massachusetts: MIT Press, 249-79. 